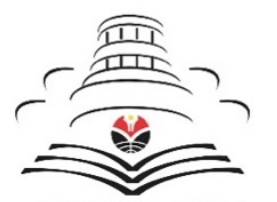

JURNAL UPI

\title{
JAPANEDU:
}

Jurnal Pendidikan dan Pengajaran Bahasa Jepang

http://ejournal.upi.edu/index.php/japanedu/index

\section{Re-discussion on the Relation Between Nihonjijou Course and Cultivation of Intercultural Communication Competence Indonesian Case}

\author{
Jeni Putra \\ Kyushu University, Fukuoka, Japan \\ jeniputra-89@gmail.com
}

\begin{abstract}
A B S T R A C T
This study backgrounded by the difficulties to cultivate Intercultural Communication Competence (ICC) in Japanese language learning in Indonesia. In learning Japanese as foreign language, knowing about latest condition and information about Japan is important. Therefore, nihonjijo (knowledge about Japan) course is taught as an essential course. However, with changing world and society, the inevitability of nihonjijou as Japanese cultural course has to be rediscussed. This study aims to find out how nihonjijou course can support the cultivation of the ICC, and how it can be reflected in nihonijou course. Literature survey was used in this study. The results showed that Japanese cultural knowledge as material of nihonjijou course are able to cultivate the ICC. However, the learning materials used in nihonjijou tend to functioned as communication medium than as culture knowledge. Furthermore, Japanese learners need to think and analyse the cultural concept trough their perspective autonomously while teachers need to act as the facilitator who supports the cultural learning process. The teaching of nihonjijou also need to be integrated with the other courses to improve its' effectivity.
\end{abstract}

\section{K E Y W O R D S}

Intercultural communication; Intercultural Communication Competence (ICC); JFL environment; Nihonjijou course

First received: 17 April 2019 A R T I C L E I N F O Available online: 28 June 2019 Final proof accepted: 27 June 2019

はじめに
インドネシアと日本の関係がより親密になって いくにつれ、インドネシア人日本語学習者と日 本語母語話者の直接的接触の機会も増えてくる ことが予測できる。インドネシアと日本の文化 的背景は異なるため、このような接触機会は異 文化コミュニケーションと呼ばれ、双方に異文

化コミュニケーション能力が求められる。そこ で、この異文化コミュニケーション能力の育成 に関して、インドネシアにおける日本語教育機 関への期待が高まっている。

国際交流基金（2016）の調査による現在の 日本語学習者数を見れば、インドネシアは世界 第 2 位となっていると同時に、以前からいくつ かの問題や課題が指摘されてきた。例えば、教 
師の日本語能力の低さ（Danasasmita:2010）や インドネシア国内の教材不足、教師の資質の問 題といった、日本語の教授に関する問題が明ら かにされている。このような問題は外国語とし ての日本語でコミュニケーションする際に起こ る問題の要因に関わっており、「日本人は物事 が決まるまで、時間がかかる」、「何かについ て言い過ぎる」といった問題が日本や日本人に 関わる仕事に就いたインドネシア人を対象にし た Widianti（2016）及び調査から分かっている が、こういった問題は日本語能力ばかりでなく、 文化理解にも深く関わっていると考えられる。

日本文化・日本社会をより深く理解するた めの授業は、日本における日本語教育では「日 本事情コース」という名前が知られて久しい。 細川（1999）は、日本事情 - 日本文化教育の重 要な項目は他者との相互関係をどのように確立 或いは保持するかであり、主課題として、文化 は知識としての文化でなく、能力としての文化 をどのように体得していくかを教授する必要が あるとしている。これを踏まえて、教師から学 習者に知識を移動させるこれまでのインドネシ アの日本文化の教授法は改善すべきだと考えら れる。一方、インドネシアの学部の場合、日本 語教育学科、日本文学学科といった日本語教育 を行っている教育機関のカリキュラムを見ると、 日本事情はもちろん、日本文化や日本社会文化 といった科目名で設定しているところも多数あ る。このような日本語関係の学科などが掲げる 最終目的は、学習者が日本語でコミュニケーシ ヨンできる能力を身につけることでもある。し かし、インドネシアと日本は文化背景が異なる ため、日本語母語話者と日本語で接触するイン ドネシア人には異文化コミュニケーション力が 必要であるものの、日本文化を扱う日本事情コ 一スで学習する文化項目は異文化コミュニケー ションとどのような関わりがありどのように役 に立つかについてまだ不明な点があるため、再 考する必要がある。

インドネシアには、日本事情コースはもち ろん、外国語教育における文化教授基準がない ため、担当する教師によって文化項目の学習内 容が異なってくる。この点については、アメリ カやオーストラリア、韓国の政府や学会が決定 した文化教授基準のような外国語教育における 文化教育方針がインドネシアには存在しないた めだとも言える。文化を扱う日本事情コースを 再考すべき理由の一つとして文化的背景の相違
は言うまでもないが、異文化コミュニケーショ ンの育成に必要とされる日本語母語話者との直 接接触の機会がインドネシアの JFL 環境では希 少であることも挙げられる。異文化コミュニケ ーションに関わる目に見える文化の相違はもち ろん、コミュニケーションスタイル、価值観、 規範、などといった見えない文化も含まれてい るため、異文化コミュニケーション能力の育成 は単純ではない。そういった文化的要素はイン ターアクションに関する文化の要素でもあるた め、学習コンテンツはそういった文化項目をよ り重視する必要がある。学習者がコミュニケー ションにおいての問題についての対策方法を学 ぶことができれば、コミュニケーションの問題 を起こすリスクを軽減させる可能性が高まると 考えられる。

\section{研究方法及び課題}

本研究は文献調查、即ち先行文献や理論、本研 究のテーマに関連する最新の文献や先行研究な ごを渉猟することで、研究課題の解明をこなす。 ここでの研究課題は、(1)日本語教育における日 本事情と異文化コミュニケーションとの関わり はどのようになっているか、(2)そしてその能力 の育成を促すためにはどのような日本事情の学 習コンテンツが必要か、(3)どのような教授方法 が必要であるか、の 3 点である。

先行研究が以前から指摘しているように、 インドネシアのような JFL 環境では異文化コミ ユニケーション能力の育成に必要とされている 日本語母語話者と直接的な接触の機会が希少で あることが、異文化コミュニケーション能力が 伸びにくいという要素に関わると考えられる。 したがってこの文献調査により、異文化コミュ ニケーション能力の育成に関わる困難を軽減さ せることが期待される。

\section{分析・考察}

これまで、日本事情の授業で異文化コミュニケ ーション能力を促すための研究として、文献調 査や実践研究などが行われてきている。小川

（2013）は学習者が実際に議論したい内容を把 握し、関心のあるテーマを取り上げ、教師と学 習者、および学習者同士の協働によって、知的 な好奇心を刺激し、活発的な授業を展開する試 
みを行った。小川の教室活動は、グループを儲 け、その中で討論するというパターンの活動で 授業が行われた。その結果、学習者が自分自身 の視点を獲得することで、自分と他者の違いや その関係性について認識できた。また、社会集 団におけるコミュニケーションを行う訓練がで きること、討論によって様々な意見を引き出せ ること、自国と他国の異文化関係にある人々と 異なる見方や考え方に気づけること、共生する 事の難しさがある一方分かち合える喜びが体験 できたことは非常に有意義であることなどがア ンケート調査から分かった。金子（2015）は実 践研究として、異文化トレーニング授業を行っ た結果、対象者は異文化コミュニケーションに 関する理論をより理解し、コミュニケーション への自信や意欲を高めることができたとしてい る。園田他（2008）は、26名の日本人学生及 び 9 名の留学生を対象とし、異文化コミュニケ ーション能力を高めるために行ったラーニン グ・ジャーナル教授法の結果を分析した。学習 者にとっては、記述を残すことによりいつでも 振り返ることができる重要な学習リソースとな っており、学習の意識化に役立っている一方、 教師にとっては受講生の学習プロセスを視覚的 に確認できるという点で有効性の高いツールで あるとしている。

安井（2009）は 20 名の留学生（国籍が多様） と 10 名の日本人学生に対して、留学生別科 (南山大学) の日本語コースでの合同授業を 8 週間連続で行った。授業では、ディスカッショ ンやディベートといったインターアクションを 中心とした活動が多く行われた。授業が終了し た後に受講者にアンケートを実施した結果、留 学生と日本人学生は「交流機会」と「異文化間 教育及び異文化体験」を求めているといった共 通点があることが分かった。また、この授業を 受けることによって、日本語で話寸機会になっ た一方、日本人学生は母国や母国語を見直し、

「視野拡大」という副産物を得ていると安井は 明らかにしている。

日本での日本事情コースは学習者の異文化 適応能力への育成に重視し、学習者が自ら異文 化体験や文化的背景が異なる話し相手とインタ ーアクションをすることによって、異文化コミ ユニケーション能力の育成プロセスを促すと言 える。しかし、日本語母語話者と直接なインタ ーアクションが希少であるインドネシアの JFL 環境は同じような育成し方を実行することが困
難であるため、異文化コミュニケーション能力 の育成に必要とされる日本語母語話者との直接 なインターアクションや文化体験が欠けている。 また、これまでの学習項目は Putra (2018) が 述べているように、日本事情コースの学習コン テンツは知識的な項目に傾いているため、日本 語母語話者とコミュニケーションを行う際にど のような役割をしているかという点にも疑問に 思う。

\section{インドネシアの日本語教育事情}

歴史的には 1960 年代に高等教育機関を中心に 日本語教育が展開され、1980 年代以降、後期 中等教育或いは高校での日本語教育が盛んにな ったが、これまでは後期中等教育の日本語学習 者がインドネシアの日本語学習者全数の大部分 を占めている。国際交流基金（2016）の調査で は、インドネシアの日本語学習者数は世界第 2 位だと報告されている。しかし、日本語学習者 数が多いといっても、日本語教育に問題がない という意味ではない。高等教育機関での日本語 教育に注目すると、相応している教材の不足や 教師の指導能力、教師の日本語能力といった問 題も先行研究で指摘されている。また、日系企 業や日本社会に関わる職種に就いている日本語 学科の卒業生を対象とした調査の結果によると、 日本語の曖昧な表現、敬語の使い方、意思決定 といった社会的コミュニケーション行動に困難 や違和感を感じることも少なくないと報告され ている。このようなコミュニケーションにおけ る問題は日本語能力に関わることはもちろん、 日本文化理解にも関わるため、日本文化を対象 にしている日本事情コースを対象とし、本論で そのあり方を再考したい。

海外では、国によって日本事情教育の背景 は様々である。例えば、北村（2011）は、他の 国と比べて日本に関する情報量が多い台湾では、 日本語教育にもその影響があり、学習者の日本 に関する知識が豊富だと述べている。そのよう な国で日本事情コースを取り扱うことは、簡単 なことではないとのことだ。北村が実践したコ 一スでは、教師は学習者に日本文化項目を教え る形式ではなく、プロセス重視型のアプローチ に重点を置き、事象を提示して学習者に考えさ せることで、自分とは異なる価值観や考え方を 理解することができ、視野を広げる姿勢を養う ことができると述べている。台湾と異なり、イ 
ンドネシアでは日本に関する情報量が多くなく、 学習者の日本事情に関するニーズも異なってく る。高岦他（2016） は、インドネシアの国立ガ ネシャ大学において、アクティブラーニングを 授業に取り入れた実践研究を報告した。授業の 項目は国の紹介や言語、季節、伝統、都道府県、 そして文化であった。この実践は、学習者の参 加及びやり取り、自国との比較、学習者の環境 へのフォーカス、多彩なグループ活動、教師か らの主体授業、そして学習者が日本語で意見を 述べる機会といった $5 つ の$ 原理から組み立てら れた。結果としては、学習者の日本語で意見を 表す力が高まり、授業にもより一層積極的に参 加した。また、学習者は自文化について日本語 で意見が表せるようになり、日本文化への関心 がより高まった上に、日本語非母語話者の教師 にも日本語授業にアクティブラーニングを応用 することを奨励した。また、Diner（2014）は、 インドネシアの日本事情コースに国際交流基金 が紹介した「エリンが挑戦シリーズ」を用いて 日本事情コースを行った。「エリンが挑戦シリ ーズ」には日本文化に関するテーマがあるため、 これらを主教材として用いており、文化学習活 動は $70 \%$ が理論的学習、30\%が体験的学習と のことだった。実践的調査を行った結果は、学 生からの評価が高く、日本語で話寸自信を向上 させることができたということがアンケートの 分析の結果から明らかになった。Aneros 他 (2017）は、アクティブラーニングのアプロー チを行うことで、日本文化理解を向上させる実 践を行った。その結果、日本事情に関する理解 や語彙も向上し、小作文を書く力も上がったと のことだった。

日本における異文化コミュニケーション教 育では、異文化理解の授業はもちろん、日本事 情の授業にも促されていることが先行研究から 分かった。授業のシステムは留学生と日本人学 生とのインターアクションを中心とし、文化や 価值観等の相違点を気づかせることで、異文化 コミュニケーション能力を啓発的に獲得させて いる。これに対して、インドネシアの場合は教 師から学習者に知識等を移転させる日本事情コ ースの授業が殆どだった。更に、インドネシア の場合、日本人とインターアクションすること で、異文化コミュニケーション教育的な日本事 情コースの実行が難しく、教材の適当さ、教師 の日本語能力や資質の問題なども指摘されてい る。また、日本文化の学習テーマとしては、イ
ンターアクションや体験中心、ソシアルスキル 項目に重点を置いている日本の日本事情コース と異なり、インドネシアでは知識的な文化項目 に重きが置かれている。これらを踏まえて、イ ンドネシアにおいてこれまでに行われてきた日 本事情コースの内容は、再考すべきであると考 えられる。

細川（1999）が述べているように、日本事 情コースにおいて注目すべき文化項目は、人間 関係に関わる項目、つまり人間関係というもの はどのように確立し、どのように保持していく べきかといったことに目を傾けるべきである。 また、日本事情コースの主な目的は目標文化を 理解することで、異文化適応能力や異文化コミ ユニケーション能力の育成を支援する役割が狙 いであるため、このコースで学習する文化項目 は文化背景が異なる人とのコミュニケーション 能力を育成するに役立つ学習項目が欠かせない と言える。

\section{日本事情教育のありかた}

以前に指摘されたように、日本事情教育の学習 内容として知識的な項目を設定すると、単に教 師から学習者に知識を移動するだけの学習方法 になってしまいがちである。例えば、学習項目 として日本の社会や生活に密着している事柄な どを教師が教える場合は、学習者が消極的な聞 き手になってしまう可能性が大きいということ も先行研究で指摘されている。

日本で行われている日本事情教育の捉え方 は、異文化理解や適応の訓練課程などといった 知識的な内容から、スキル的な実践に変わって いる。一方、インドネシアの場合は、現在でも 知識的な学習項目を学習コンテンツとして扱っ ている日本語教育機関が多数ある。これは教師 の日本事情教育観にも関わっている。日本事情 に対する教育観が変われば、日本事情教育の内 容、即ち学習コンテンツ、評価方法、教授法な ども変わる可能性がある。

現在の日本事情教育の見方は、文化とコミ ユニケーションとの親密な関係があまり重視さ れていない、と Putra（2018）は批判している。 例えば、歌舞伎、能などの伝統芸能を学習項目 に入れるとする。実際には、一般の日本人でも 興味がない人、そのようなことに関する知識が 必要ではない人も多くいるのは事実である。そ ういった情報が必要な場合、様々な情報手段が 
存在する現在では、それに関する知識を得るの 主目的が自然な日本語でのコミュニケーション 能力を習得することであれば、それを促す異文 化理解に関わる日本文化項目を日本事情での学 習コンテンツとする必要があり、更に授業運営 を通して教師自身の学問レベルを向上させるこ とも求められる、ということも日本事情教育の 研究では大いに指摘されている。

国際文化フォーラム（2012）は文化を見え る文化及び見えない文化に分けられている。物 事や行動といった目に見える文化事象を学習者 が自ら観察することで、自立発見や気づきを促 すとのことである。さらに、価值観や考え方と いった文化事象の背景となる見えない文化につ いては、なぜ文化に同意があるのかを、学習者 が自ら調べ、考えることも重要だと述べている。
に困難がなくなった。そのため、日本語教育の 教師の役割は学習者の興味や好奇心、関心を喚 起し、適切な教材を提供したり、学習を導いた りして、学習者の観察力、想像力、調査力、分 析力などを高めることで、文化の学ぶ力が身に ついていくとのことである。

\section{日本事情教育の学習コンテンツ}

本来、日本事情コースにどのような文化的学習 のコンテンツを入れるかは学科や大学の教育方 針にも関わり、教師の教育観にも影響される。 国際交流基金（2010, p.6）は日本事情の学習コ ンテンツを $2 つ に$ 分け、1つ目を日本の生活を 知るための情報、もう 1 つを日本を知るための 情報としている。詳細は表 1 の通りである。

表 1 日本事情コンテンツ（国際交流基金 2010, p.6)

\begin{tabular}{|c|c|c|}
\hline 日本事情・日本文化 & カテゴリー & 例 \\
\hline \multirow{4}{*}{$\begin{array}{c}\text { 社会生活を知る上で } \\
\text { 必要な情報 }\end{array}$} & 対人関係 & 挨拶、名前・敬称、上下関係、親疎関係、内外関係 \\
\hline & 生活 & $\begin{array}{c}\text { 衣食住、趣味・娛楽、仕事・職業、家族構成、生活 } \\
\text { リズム、休日・休楽 }\end{array}$ \\
\hline & 社会システム & $\begin{array}{c}\text { 交通システム、生活インフラ、通信、メディア、 } \\
\text { 学校、金融、医療、行政、社会ルール }\end{array}$ \\
\hline & 習慣・慣習 & 礼儀・作法、冠婚葬祭、年中行事、贈答 \\
\hline \multirow{3}{*}{$\begin{array}{c}\text { 日本を深く理解するために } \\
\text { 必要な情報 }\end{array}$} & 伝統・芸能 & $\begin{array}{l}\text { 茶道・華道・書道、伝統芸能、柔道・空手・相撲、 } \\
\text { 日本的な遊び、サブカルチャー（映画、 } \\
\text { ドラマ、漫画、アニメ、音楽）、 }\end{array}$ \\
\hline & 社会・人文文化学 & 政治、経済、教育、歴史、宗教 \\
\hline & 自然環境 & 地理 ・気候 \\
\hline
\end{tabular}

国際交流基金が述べた文化のカテゴリーを 考えると、現在インドネシアの多くの大学が設 置している項目は所産・知識的な文化に傾いて いると Putra（2018）は指摘している。これは 決して欠陷とまでは言えないが、インドネシア と日本の文化が異なることを考えれば、コミュ ニケーションスキルをサポートする文化概念に ついての理解の必要性を念頭に置き、これまで の文化の学習コンテンツのあり方を考え直すこ と、さらには異文化コミュニケーションに必要 とされる異文化理解はどのような文化なのかを 再考し、日本事情コースに反映する必要がある。

\section{日本事情と異文化コミュニケーションの関 連性}

異文化コミュニケーションは先行研究で様々な 定義がなされてきたが、共通しているのは、異 文化コミュニケーションはコミュニケーション 能力と異文化理解から成り立つものであるとい うことである。前述のように、世界において文 化の普遍性を中心とする観点は「文化一般」と 呼ばれているのに対して、日本文化や韓国文化、 アメリカ文化などといった文化の特徴に焦点を 当てる領域は「文化特定」と呼ばれている。後 者のような 1 つの「文化特定」の環境に生まれ 育った人が異なる「文化特定」からの人とコミ 
ユニケーションを行う場合、必ず文化的な共通 点と相違点がある。その際にコミュニケーショ ンの障害を削減するためには、コミュニケーシ ヨン能力はもちろん、異文化理解も不可欠なも のである。このような場合を異文化コミュニケ ーションの場面と呼ぶ。

異文化コミュニケーション過程において、 自文化と他文化の特性を理解すると同時に、そ れぞれの文化がコミュニケーションにどのよう な影響を与えるかといった知識が異文化コミュ ニケーション研究では重要な項目である。そこ で日本事情コースは、異文化コミュニケーショ ン能力に必要とされる文化的項目を提供できる のではないかと考える。

Sarbaugh 他（1983）は、異文化コミュニケ ーションの理論的な視点を三つ述べている。ま ず、異文化コミュニケーションは一般のコミュ ニケーションの拡大であり、異文化または同文 化の変数は同じである。二つ目は研究分野とし て、異文化コミュニケーションは文化が異なる 個人或いは集団レベルでのコミュニケーション の問題になる要因に焦点を当てている。最後に、 異文化コミュニケーション研究における実践の 指針は、人間コミュニケーションの研究の基礎 となる理論的な視点である。異文化コミュニケ ーションを研究の対象とする場合は、このよう な 3 つの前提を考えなくてはならず、これらは 最低限の条件であるとも言えよう。

\section{異文化コミュニケーションの目的}

石井他（1996）は、異文化コミュニケーション の目的を、異文化相互理解に対する積極的な態 度の養成と世界的展望をもつ人間観の確率であ り、異文化の接触に必要な適応力の養成、また、 学校や職場における教育の一部をなす実際的異 文化コミュニケーション技能の養成であるとし ている。グローバル化が進んでいる現在では、 政府間の外交はもちろん、個人と個人の交渉の レベルでも異文化コミュニケーションを行う機 会が増えている。このような状況では、個人が 持つ異文化コミュニケーション能力の育成を促 進する方法の一つとして、外国語教育の観点か ら、異文化コミュニケーション教育を展開させ ることも不可欠だと言えるだろう。

Spitzberg（1991）は異文化コミュニケーシ ヨンの定義を個人内の能力だと出張しており、 価值と規範といった異文化コミュニケーション
における変数を態度や発話で具体化することで、 有効なコミュニケーションに移る能力だと述べ ている。コミュニケーション能力は先行研究で は様々な定義が為されているが、共通するのは、 文法的な正しさはもちろん、コミュニケーショ ンにおいての態度や行為が適当であることが求 められるという点である。また、異文化コミュ ニケーション能力の場合は、社会や文化的な価 值や規範に相応することも必要である。

\section{異文化コミュニケーションに向けた日本事 情コース}

日本語教育において、中崎（2005）は日本語能 力を獲得する指導に加え、学習者が学びたい項 目や学習者の専門に関わる項目を重視し、異文 化環境での問題解決能力を育成することが教師 の重要な役割であるとしている。更に、学習支 援、キャリア支援といった異文化環境としての 現実の日本社会で生きる能力を主体的に確立さ せるための支援などがカリキュラム上で具体化 させる必要があるとも述べている。小川（2013） は、「学習者が主体的に異文化と自文化の関係 を体得する総合学習を捉えるのには教師が学習 者の実際に議論したい内容を把握し、関心のあ る共通のテーマを取り上げ、教師と学習者、及 び学習者同士の協働によって、知的好奇心を刺 激して活発な授業を展開することが求められる」 と述べている。久保田（2008）も、日本文化を 学習者がクリティカルに見て、それを学び、理 解することが望ましいとしている。つまり、日 本事情教育を通して、学習者は日本文化を理解 するために自らの観点で文化を検討して体得す る、と結論づけられる。文化とコミュニケーシ ヨンの関係を再考すると、相互の関連性は様々 ある。例えば石井他（1996）は、コミュニケー ションを行うことによって文化を体得し、文化 を通じて適切なコミュニケーションの活動方法 を学ぶという課程を述べており、社会的な環境 における文化とコミュニケーションの関係の見 方を示している。

日本語での異文化コミュニケーション能力 を育成するためには、異文化適応能力も必要で あり、三代（2009）は日本語能力は異文化適応 の一要因であり、日本文化やソーシャルスキル を教えることで、学習者のコミュニケーション 能力も向上するという考え方を示している。島 崎（2016）はアクティブラーニングを実行し、 
$\lceil$ Understanding Japan through Miyagi's Traditional Culture」というコースに応用し、本 コースでは英語を教授言語にして、日本人学生 や留学生向けに開講された。本コースの目的は、 伝統文化の理解を通して日本への理解を深める ことであり、特に地域文化に学習者の目を向け させるということである。

さらに新崎（2007）は、異文化コミュニケ ーション能力の育成方法を 2 つに分けている。 それは知識型と体験型である。知識型は言わば 講義、ビデオ視聴、ディスカッション、ケース スタディなどである。一方、体験型はロールプ レー、シミュレーション、ワークショップとい つた、経験を通じて学習し、実際に対象文化に 身を置いて行うフィールドワークや交流活動も 体験とすることである。体験型は体験すること にのみ焦点を置きがちであるが、実際に文化を 経験することで学習者は何かを学び取り、それ を実際の生活に活かすことに繋がるため、それ を繰り返すことは学習活動に欠かすことのでき ないことだと出張している。

\section{おわりに}

以上の考察を踏まえ、日本事情コースの文化学 習項目は伝統文化及び所産 - 知識的な文化に傾 いてしまうと、異文化コミュニケーション能力 の育成につながらないという可能性もあること が明らかになった。本来の教育目的が異文化と いう壁を乗り換えてコミュニケーションできる 能力を育成することであるならば、コミュニケ ーションをすることで他者との相互関係をどの ように確立・保持するかを重視し、コミュニケ ーションを介在する文化項目により一層着目す る必要があると考えられる。また、これまでの 異文化コミュニケーションの育成モデルを見る と、異文化環境での態度や文化知識、社会文化 がキーワードになっている。教える方法に関し ては、教師から学習者へ知識を移動するのでは なく、教師は言わばファシリテーターの役割を 果たし、学習者が自ら日本文化を発見して体験 することで、文化を啓発的に体得していく教室 活動の展開が必要であると考えられる。今回、 日本事情コースのあり方について再考してきた が、日本語母語話者や日本文化に接触する機会 が希少であるインドネシアのような JFL 環境に おいて、異文化コミュニケーション能力を育成
するためにどのような方法が必要かということ に関しては、検討すべき大きな課題として残っ ている。

\section{参考文献}

Aneros, N., Judiasri, M. D., \& Herniwati. (2017). Penerapan Active Learning pada Pembelajaran Choukai Untuk Meningkatkan Pemahaman Nihonjijo. http://repository.umy.ac.id/bitstream/handle/123 456789/17413/full.pdf?sequence=1\&isAllowed=y (diambil pada 28 September 2018)

Danasasmita, W. (2010) . Pendidikan Bahasa Jepang di Indonesia Sebuah Refleksi. Repositori UPI. Universitas Pendidikan Indonesia. [ http://file.upi.edu/Direktori/FPBS/JUR. PEN D. BAHASA JEPANG/195201281982031WAWAN DANASASMITA/Makalah/43B05 1. pdf] (diambil pada 12 Agustus 2017)

Diner, L. (2014). Pembelajaran Budaya Jepang Melalui DVD Erin ga Chousen. https://media.neliti.com/media/publications/9100 0-ID-pembelajaran-budaya-jepang-melaluimedia.pdf (diambil pada 28 April 2018)

Putra, J. (2018) 日本事情教育における異文化コミュ ニケーション能力の育成を促す方法. International Conference on Japanese Language Education 2018: Japanese Language Education and Its Relationship to Bussines World.

Sarbaugh, L., \& Asuncion-Lande, N.(1983). Theory Building in Intercultural Communication: Synthesizing the Action Caucus. In W. B. Gudykunst (Ed.), Intercultural Communication Theory: Current Perspective. International and Intercultural Communication Annual (Vol. 8, pp. 4560). Beverly hills, California: Sage.

Spitzberg, B. H. (1991). Intercultural Communication Competence. In L. Samovar \& R. Porter (Eds.), Intercultural Communication (pp. 353-365). Belmont, CA: Wadsworth.

Widianti, S. (2016). 日系企業におけるインドネシア人 のコミュニケーション. 2016 年日本語教育国際研 究大会.

安井朱美（2009）「留学生と日本人学生との合同授 業の試みーコメントから見えてくるものー」 http://office.nanzan-u.ac.jp/ncia/aboutcia/item/pdf 09/jissen 03.pdf（最終検索日：2018 年 1 月 28 日)

園田博文、奥村圭子 \& 中村朱美（2008）「異文化能 カとコミュニケーション能力の養成にむけて 山梨大学・山形大学・佐賀大学の授業実践を事例 として一」『山形大学紀要 (教育学科)』，14(3), 55-77.

久保田竜子(2008)「日本文化を批判的に教える」佐 藤慎司・ドーア根理子編『文化、ことば、教育 
一日本語/日本の教育の「標準」を越えて一』 (pp.151-173). 明石書店

金子正子（2015）「大学における異文化コミュニケ ーション能力を育てる授業の試み一受講者の気 づきに注目してー」教育実践ノート [ http://www.mukogawau.ac.jp/ edugrad/1006kaneko.pdf]) （最終検 索日: 2017 年 8 月 10 日)

高峷幸子 \& 都恩珍（2016）「海外の日本語学習者に 日本文化をどう教えるかーアクティブラーニング を取り入れた授業の試み一」JLSA, 8, 115-127.

国際交流基金（2016）「2015 年度海外日本語教育機 関調查結果（速報值） 2016/11/10」 〔 http://www.jpfbj.cn/sys/wpcontent/uploads/2016/11/2015 jieguoshuoming.p df]（最終検索日：2017年 6 月 10 日） る』ひつじ書房

（2010）『日本事情・日本文化を教え

国際文化フォーラム（2012）「外国語学習のめやす 一高等学校の中国語と韓国語教育からの提言一」 $\mathrm{PDF}$ http://www.tjf.or.jp/pdf/meyasu web.pdf (最終 検索日：2018 年 6 月 10 日)

細川英雄（1999）『日本語教育と日本事情一異文化 を超える一』明石書店

三代純平 (2009) 「留学生活を支えるための日本語 教育とその研究の課題 一社会構成主義からの示 唆一」『言語文化教育研究』, 7(8), 65-99.

小川都（2013）「留学生に必要とされる『一般日 本事情』のあり方」『専修大学外国語教育論集』 41, 105-113.

新崎隆子 (2007) 「異文化コミュニケーション能力の 修得プロセス〜通訳演習参加者の事例より」日本 通訳学会第 8 会大会発表配布資料

石井敏, 岡部朗一 \& 久米昭元著（1996）『異文化コ ミュニケーション: 新・国際人への条件』有斐閣 選書

中崎温子（2005）「多文化共生社会の日本語教育-「コミュニケーション」ということの考察を通し て」『言語と文化』，13,103-120.

島崎 薰（2016）「日本文化のクラスにおけるアクテ ィブラーニングの実践 一すずめ踊りプロジェク トでのアクション・リサーチを通した一考察一」 『東北大学高度教養教育・学生支援機構紀要』, 2 , 181-191.

北村武士（2011）「日本事情・日本文化を取り入れ た日本語授業を考える一国際交流基金教授法シリ 一ズ『日本事情・日本文化を教える』より一」 https://www.koryu.or.jp/Portals/0/resources/kao hsiung/ez3 contents nsf/15aef977a6d6761f49256d e4002084ae/b23cb5657c97286049257825002658fe/ \$FILE/dai\%20san\%20kai\%20jyunkai\%20handout. pdf（最終検索日：2017 年 6 月 13 日） 